\title{
Mekâna Yerleşmek, Yaşamı Paylaşmak: Bir Arada Yaşamak*
}

\section{Nilgün Toker Kılınç**}

Öncelikle birlikte yaşamak terimine itirazla başlamak isterim. Çünkü eğer bir birleşmeden (unification), bir bağlanmadan bahsetmiyorsak, birlikte yaşam ifadesi uygun değil. Birlikte yaşamanın kendi kültürümüzdeki anlamı bağlanmayı ifade eder: Bir tür bağlanmayı...

$\mathrm{Bu}$, Ingilizce with ya da Fransızca avec edatlarıla ifade edilen şeydir. Oysa bir ortamın paylaşılmasından bahsediyorsak, örneğin bir toplumun üyeleriysek with edatı değil, together zarfıdır söz konusu olan; yani birliktelik değil bir aradalıktır. İkisi arasındaki fark esasen şudur: Birliktelik aradaki dolayımın kalkmasıdır; bir aradalık ise dolayımsal bir paylaşımdır. Daha doğrusu bir ortamda bir arada olmak gerçekten de "arada" (in-between) olmaktır; karşılıklı bağlanma değil, farklı ilişkilenmeleri mümkün kılan aradalık halidir.

Klasik anlamda köy ve kenti birbirinden ayıran şey de işte budur: Kendiliğinden, hatta neredeyse "doğal" bir birlikte olma hali, dolayısıyla benzerlik kuran bir bağ ile iradi bir bir arada olma hali, farkıı kalma şansı arasındaki fark. Artık kentin de tarihsel "doğallığından" bahsediyor olduğumuz bir zamanda yaşıyor olsak da kentler de artık içine doğulan yerler olsa da kent herhangi bir "yakınık" olmaksızın katıınabilen yerdir. Bunu kentin aynı zamanda üretim ilişkilerinin farklılaşmasını taşıyan bir mekân olmasında da temellendirebiliriz. Bir mekânı kent yapan şey, farklı insani etkinliklerin bir arada olabilmesidir. İnsani etkinliklerin farklılaşmasının ürünü olan kent, hâlâ bu farklılaşmayı ve farkları taşıyabiliyorsa vardır. Tersi durumda, kenti sadece ekonomik etkinlikle tanımlamaya başladığımız durumda, kentler üretim köylerine dönüşmüş olur. Belki aktüel olarak tüm kentlerin aynılaşmasının nedeni de budur.

Tam bu noktada kentin referansının sadece yaşamak olmaması gerektiğini söylemeliyiz. Canlılığın sürdürülmesi anlamında yaşamak fiiliyle (living) bağlanan bir co-living terimi aslında yaşamsal ihtiyaçların karşılanması için işbirliğine işaret eden bir kavramsa eğer, kentin referansı esas itibarıyla ekonomik etkinlik olur. Oysa kent tek biçimli etkinlik alanı değil, yalnızca canlılığı, yaşamı sürdürme etkinliklerinin alanı değil, tam tersine insani etkinlikler dediğimiz, üretim etkinliğine indirgenemeyecek etkinliklerin de alanıdır. Kenti köyden ayıran şey de budur; doğal intiyaçlardan farklılaşmış insani intiyaçlara yanıt vermesidir. Estetik, politik vb. etkinliklerin çeşitlilikle gerçekleştiği alandır kent.

Bu özelliklerinden dolayı belki doğru terim kentte yaşamak değil, kentte ikamet etmek (habitation) olmalıdır. İkamet etmek, bir mekâna yerleşmek, asıında o mekânın kültürüne katılmak anlamına gelir. Yerleşmek fiili burada artık, bir ortaklığa dahil olmak, o ortaklığın değer ve alışkanlıklarını paylaşmaktır, bir habitusa bağlanmaktır.

Bir mekâna yerleşmek, o mekânı kendi ilgileriyle sürekli dönüştürmek ve o mekânı kültürel bir ortam haline getirmek aslında bir yaşamı sürdürme işbirliği değildir. Tersine kent esasen farkı ilgilerin karşılaşma alanıdır. Tam da bu karşılaşma nedeniyle bir çatışma (conflict) ama aynı zamanda çekişmeli (agonistic) bir kaynaşma alanıdır.

Antikler bu nedenle, bir yerde bir arada yaşayanların bu karşılaşma ile aralarında kurdukları bağa hemşerilik, ethos derler. Hemşerilik içine "doğulan” bir bağın adı değildir, yaşamayı seçtiğiniz bir yerde kurduğunuz iradi bağın adıdır.

\footnotetext{
* Dünya Tasarım Başkenti 2020 için İzmir adına başvurucu kurum olan İzmir Akdeniz Akademisi'nin Dünya Tasarım Örgütü işbirliğiyle 29 Haziran 2018'de düzenlediği "Birlikte Yaşamak İzmir" temalı Dünya Tasarım Konuşmaları'nda sunulan çerçeve metin.

** Türkiye İnsan Hakları Vakfı, İzmir Dayanışma Akademisi
} 
Roma'dan itibaren, bu karşılaşma ile oluşan kültüre habitus adı verildi. Kastedilen ortak davranış kuralları, karşılaşanların birbirleriyle kurdukları ilişkilerin etik kodlarıdır. Aslında bir ortak yaşam tarzını ifade eden bu kavram, her bir kente özgü bir yaşam tarzının olması gerektiğini de bize öğretir. Kent kimliğinin dayanağı da budur: 0 kentte birlikte yaşama tarzına ve dolayısıyla kültürüne sahip olma. Bir tarzın olabilmesi, kentlerin aynı biçimle tasarlanmış, biçimlendirilmiş ve inşa edilmiş yapılar olarak düşünülmemesi, tam tersine hemşerilerin özgür edim ve etkinlikleriyle kurdukları, diğerlerinden farklı bir tarza sahip olmalarını mümkün kılan dinamik alanlar olarak görülmesi gereklidir.

Kent doğal birlikteliklerin kavramlarılla okunamaz. Örneğin aile bağıyla, hısımlıkla açıklandığında kent, köyün kavramlarıyla okunmuş olur. Kentin yurttaşları arasındaki bağın dayanağı "sevgi" değil, eşit ve farklı olduğunun kabulüne dayalı "saygı"dır.

Saygı, tanıma (recognition) ilişkisini ön gerektirir. Diğerinin varı̆̆ını ve ilgisinin farkını kabul etme, onun ilgisinin kendi ilginle aynı olmasını değil ama eş-değer olmasını ilan etmedir.

Bu eş-değerlik nedeniyle kent, herkesin kendi ilgisini, özgürlüğünü diğerlerinin huzurunda gerçekleştirmesini mümkün kılacak olan dolayımın adıdır. Bir arada yaşam da budur. Kendisini diğerlerinin huzurunda görünür kılma alanı. Bu nedenle her bir insani edim, kendi değer onayını almak ve dolayısıyla her bir kişi kendi değerini diğerinin dolayımıyla tanımak için bu bir aradalık haline intiyaç duyar. Kent yurttaşlarının birbirlerinin varlığına bağlı varoluşlarının anlamı budur. Diğerinin olmadığı yerde ben kurulamaz.

O halde bu bir aradalığı koruyacak kavramın ne olduğunu söyleyerek bitirelim: Özen. Her bir kentlinin hemşerisine göstermesi gereken özen ama daha önemlisi bu mekânı kent kılmakla yükümlü olanların, bu dolayımın özgür bir karşılaşma mekânı olarak varlığını sürdürmesiyle yükümlü olanların tümünün yurttaşlara göstermesi gereken özen.

Özen, kentin ortak yaşamının dayanağı olacak ahlaksal kod olarak da okunabilir. Hemşerilik bağı, herkesin birbirine özenli davranmasını gerektiren, bu nedenle de diğerinin özgürlüğüne ve farkına saygıdan kaynaklanan sorumluluk içeren bir bağdır. 